\title{
ERRATUM
}

Margie M. Paz • Juan Carlos Martinez •

Andrea B. Kalvig • Tina M. Fonger · Kan Wang

\section{Improved cotyledonary node method using an alternative explant derived from mature seed for efficient Agrobacterium-mediated soybean transformation}

Published online: 14 February 2006

(C) Springer-Verlag 2005

\section{Plant Cell Reports DOI 10.1007/s00299-005-0048-7}

Materials and methods, subsection Agrobacterium culture and infection medium, the fourth sentence should read:

On the day of infection, a bacterial pellet was obtained by spinning the overnight culture at $3500 \mathrm{rpm}$ for $10 \mathrm{~min}$ and resuspended in infection medium containing $1 / 10$ strength Gamborg's B5 salts (Gamborg et al. 1968), B5 vitamins, and 1/5 strength MSIII iron stock (Murashige and Skoog 1962), with 7.5 $\mu \mathrm{M}$ 6-benzylaminopurine (BAP), $0.7 \mu \mathrm{M}$ gibberellic acid $\left(\mathrm{GA}_{3}\right), 20 \mathrm{mM}$ MES [2-( $N$-morpholino) ethanesulfonic acid], 3\% sucrose and $200 \mu \mathrm{M}$ acetosyringone, $\mathrm{pH}$ 5.4.

Materials and methods, subsection Explant preparation and infection, the seventh sentence should read:

The cocultivation medium is infection medium with $100-400 \mathrm{mg} \mathrm{l}^{-1}$ cysteine and $154 \mathrm{mg} \mathrm{l}^{-1}$ dithiothreitol, pH 5.4, and solidified with $0.425 \%$ Noble agar (Fisher Scientific, USA).

The online version of the original article can be found at http://dx.doi.org/ 10.1007/s00299-005-0048-7

M. M. Paz · J. C. Martinez - A. B. Kalvig - T. M. Fonger ·

K. Wang $(\square)$

Department of Agoronomy, Iowa State University,

Ames, IA 50011-1010

e-mail: Kanwang@Iastate.edu

Tel.: +515-294-4429

Fax: +515-294-2299 